\title{
Defect of a Complement Receptor 3 Epitope in a Patient with Systemic Lupus Erythematosus
}

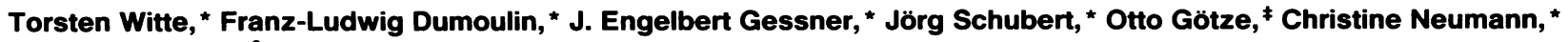 \\ Robert F. Todd III, ${ }^{3}$ Helmuth Deicher, * and Reinhold E. Schmidt* \\ *Abteilung Klinische Immunologie und Dermatologie, Zentrum Innere Medizin und Dermatologie, Medizinische Hochschule Hannover, \\ 3000 Hannover 61, Germany; ${ }^{\ddagger}$ Abteilung Immunologie, Zentrum Hygiene und Humangenetik, Universität Göttingen, Germany; and \\ ${ }^{\S}$ Division of Hematology and Oncology, Internal Medicine, Simpson Memorial Research Institute, University of Michigan, Ann Arbor, \\ Michigan
}

\section{Abstract}

Complement receptor $3(\mathrm{CR3})$ is expressed on cells of the reticuloendothelial system and involved in the clearance of immune complexes. In this article a patient with a deficiency of the $\mathrm{C} 3 \mathrm{bi}$ binding site of this receptor is described. Clinically this patient exhibited predominantly cutaneous manifestations of a systemic lupus erythematosus with an immune vasculitis and panniculitis.

The deficiency of the CR3 epitope was demonstrated using flow cytometry. The functional relevance of this defect was demonstrated in a rosetting assay with C3bi-loaded erythrocytes. C3bi binding was found to be significantly decreased. Furthermore, there was an impairment of phagocytosis of opsonized Escherichia coli. The CR3 defect is not due to an autoantibody but is assumed to have a genetic basis. These data suggest that the defect of the CR3 may be involved in the pathogenesis of the immune vasculitis in this patient. (J. Clin. Invest. 1993. 92:1181-1187.) Key words: complement receptor $3 \cdot$ systemic lupus erythematosus • vasculitis • immune complexes • clearance

\section{Introduction}

SLE is associated with a decreased clearance of immune complexes (1). Immune complexes appear to contribute to a major extent to the pathophysiology of systemic vasculitis by activating $\mathrm{Fc}$ receptor and complement receptor-positive mononuclear cells $(2,3)$. A decreased solubilization of immune complexes is suggested as one of the most important factors leading to pathogenic concentrations of complexes. $\mathrm{C} 2$ and $\mathrm{C} 4$ deficiencies which may be responsible for decreased immune complex solubilization have been observed in increased frequency in patients with SLE (4-6). Also, in addition to genetic and environmental factors, cell surface receptors responsible for the clearing of immune complexes are likely to represent one of the factors contributing to this autoimmune disease (7).

Clearance of immune complexes is mediated in part by complement receptors that are expressed on erythrocytes $(\mathrm{CR} 1)^{1}$ and cells of the reticuloendothelial system in liver and

Address correspondence to Reinhold E. Schmidt, M.D., Abteilung Klinische Immunologie, Zentrum Innere Medizin und Dermatologie, Postfach 616180, 3000 Hannover 61, Federal Republic of Germany.

Received for publication 4 November 1992 and in revised form 26 March 1993.

J. Clin. Invest.

(c) The American Society for Clinical Investigation, Inc.

0021-9738/93/09/1181/07 \$2.00

Volume 92, September 1993, 1181-1187 spleen (CR3, CR4). These receptors participate in the transport, recognition and uptake of circulating immune complexes into these cells.

In this article, we report on a patient with SLE exhibiting a complement receptor 3 (CR3) deficiency. The defect is demonstrated by a lack of expression of the critical C3bi binding epitope and by a defective function of the receptor. Our results suggest that the lack of this particular C3bi binding epitope defines a new pathogenetic entity contributing to the pathogenesis of SLE.

Case report. A 38-yr-old male Turkish patient with discoid facial lesions was first seen in the immunological outpatient clinic of the Medizinische Hochschule Hannover in 1981. A serological investigation revealed antinuclear, anti-dsDNA antibodies, anti-Sm and RNP antibodies. The disease was diagnosed as a discoid lupus erythematosus. In 1986 he developed several episodes of arthralgias, Raynaud's phenomenon, a panniculitis and a vasculitis, predominantly affecting the distal extremities. Histologically the vasculitis was characterized by pericapillary predominantly lymphocytic infiltrates. In addition a photosensitivity and a malar rash were noted. At this time the diagnosis was changed to systemic lupus erythematosus because the patient fulfilled six American Rheumatism Association criteria (8). During acute vasculitic episodes acute phase proteins were elevated, complement levels $(\mathrm{C} 3, \mathrm{C} 4, \mathrm{CH} 50)$ were decreased, and a mild proteinuria was observed. Elevated immune complex levels were detected in a radial immunodiffusion assay. Flares of the vasculitis required treatment with high doses of steroids and azathioprine.

In 1975 the patient had suffered from tuberculosis. Antibodies against hepatitis A and B virus indicated earlier infections with both viruses. His family history did not reveal any particular susceptibility to infections.

\section{Methods}

Monoclonal antibodies. Antibodies LPM19C, 14B6.E2, VIM12, TMG6-5, and MN41, recognizing the CD11b (CR3) antigen, were taken from the antibody panel of the IVth International Workshop for Leucocyte Typing (9). Additional CD1 1 b antibodies (mAb 94 [ monocyte (Mo) 1], mAb 17, defining epitope 17, and mAb 44), directed against different epitopes of the CR3, have been described in detail previously (10). To5 binds to CR1 (CD35) (11). B2 defines the CR2 (CD21) and B-Ly6 the CR4 (CD11c) $(9,12)$. MHM23 (CD18) reacts with the common $\beta$-chain of CD1 la, CD1 lb, and CD11c (9). $2 \mathrm{~F} 12$ binds to $\operatorname{CD} 11 \mathrm{a}(9,13)$.

Cell preparation and phenotypic studies. $\mathrm{PBMC}$ were isolated from the interphase of a Ficoll-Isopaque gradient (Biochrom, Berlin, Germany) (14). Granulocytes (PMN) were purified from the pellet by

1. Abbreviations used in this paper: CR, complement receptor; IC, immune complexes; Mo, monocyte. 
incubation in 5\% hydroxyethylstarch for $60 \mathrm{~min}$. The supernatant was centrifuged and erythrocytes lysed by incubation in distilled water for $60 \mathrm{~s}$.

Cell surface antigens were determined using indirect immunofluorescence as previously described in detail (15). $100 \mu \mathrm{l}$ of primary antibodies were applied as ascites in dilutions of 1:200 in PBS. Analysis was performed by flow cytometry on a FACScan ${ }^{\otimes}$ (Becton Dickinson and Co., Heidelberg, Germany) counting 10,000 cells per sample. PBL and monocytes were separately investigated by gating on the different cell populations.

To block the epitope 17 with a putative autoantibody $10^{6}$ granulocytes of two healthy donors were incubated for $30 \mathrm{~min}$ at $4^{\circ} \mathrm{C}$ with either $1 \mathrm{ml}$ serum or $1 \mathrm{ml}$ immunoglobulin $(5 \mu \mathrm{g} / \mathrm{ml})$ obtained from sera of the patient or a control SLE patient using a protein $\mathrm{G}$ column. Expression of epitope 17 and the CD11b control epitope 44 was determined as described above.

Binding of patient's serum to recombinant CR3 expressed in COS cells was kindly performed by Dr. M. A. Arnaout (Massachusetts General Hospital, Boston ) (16). For the activation studies monocytes isolated from the interphase of a Ficoll-Hypaque gradient (Biochrom) were incubated for $15 \mathrm{~min}$ at $37^{\circ} \mathrm{C}$ in PBS supplemented with PMA at a concentration of $0.1 \mu \mathrm{g} / \mathrm{ml}$ or in PBS alone. Cell surface expression of $\mathrm{CD} 1 \mathrm{lb}$ epitopes was determined as described above.

Furthermore, PMN of the patient were washed three times in $0.9 \%$ $\mathrm{NaCl}$ acidified with $\mathrm{HCl}$ to $\mathrm{pH} 4.0$ or in $0.9 \% \mathrm{NaCl}$ alone. After washing the viability of the cells was determined using trypan blue staining. Viability was $>70 \%$ in three assays performed. Subsequently the expression of epitope 17 and epitope 44 as a control were examined using flow cytometry.

Generation of cell lines. Lines of peripheral blood lymphocytes containing 30\% CD16+ natural killer cells were cultured as previously described (17). Briefly, peripheral blood cells were isolated using a Ficoll-Hypaque gradient. $10^{5}$ of these cells were plated in 96-well Vbottomed plates on a feeder layer of $5 \times 10^{4} \mathrm{EBV}$-transformed B cells and $5 \times 10^{4}$ peripheral blood lymphocytes per well. Culture medium was RPMI 1640 supplemented with $10 \%$ IL-2 containing lymphocyteconditioned medium (18).

Rosetting assays. C3b-loaded sheep erythrocytes were prepared as previously described $(19,20)$. Erythrocytes loaded with C3bi were obtained by incubating $10^{8} \mathrm{C} 3 \mathrm{~b}$-loaded sheep erythrocytes with $50 \mu \mathrm{g}$ of complement proteins Factor $\mathrm{H}$ and $4 \mu \mathrm{g}$ Factor I in $1 \mathrm{ml}$ of dextrose-gelatin-veronal buffer supplemented with magnesium and calcium for $1 \mathrm{~h}$ at $37^{\circ} \mathrm{C}$. For rosette assays, $10^{6} \mathrm{PMN}$ in $100 \mu \mathrm{l}$ PBS-BSA were incubated for $30 \mathrm{~min}$ at $4^{\circ} \mathrm{C}$ with $10^{7}$ erythrocytes loaded with $\mathrm{C} 3 \mathrm{bi}$ in an equal volume. In parallel PMN were preincubated for $30 \mathrm{~min}$ with $\mathrm{mAb} 17$ in ascitic fluid diluted $1: 50$ at $4^{\circ} \mathrm{C}$ and used in the assay as described above. The percentage of PMN binding three or more erythrocytes was blindly assessed by two independent observers using a microscope at a magnification of 640 .
Phagocytosis. Freshly isolated PMN were either incubated for 30 min in PBS alone, in PBS containing 2E1 (CDw32) and 3G8 (CD16) antibodies in a dilution of $1: 50$, or in PBS containing $\mathrm{mAb} 17$ in ascitic fluid in a dilution of 1:50. Phagocytosis was determined using the commercially available Phagotest ${ }^{\star}$ (Orpegen, Heidelberg, Germany). Briefly, PMN were washed three times in RPMI 1640, then $2 \times 10^{5}$ cells were incubated with $20 \times 10^{6}$ FITC-labeled Escherichia coli in a total volume of $120 \mu \mathrm{l}$ RPMI 1640 for $10 \mathrm{~min}$ at $37^{\circ} \mathrm{C}$ in a shaking water bath. $E$. coli that were not phagocytosed were quenched at $0^{\circ} \mathrm{C}$. The percentage of PMN with FITC-labeled $E$. coli ingested was determined using a FACScan ${ }^{\otimes}$ (Becton Dickinson and Co.).

Granulocyte adherence. Adherence was tested according to a previously published method (21). $1 \mathrm{ml}$ of heparinized blood was filtered through nylon wool in pasteur pipette at room temperature. The percentage of adherent PMN was calculated as follows: (PMN in original sample - PMN in effluent sample/PMN in original sample) $\times 100$.

Immunohistology. A subcutaneously located skin nodule on the upper arm of the patient with the typical histology of lupus panniculitis and lesions of three other patients with chronic discoid lupus erythematosus as controls were biopsied after informed consent and part of the material was snap frozen. Cryostat sections $(6 \mu \mathrm{m})$ were stained using the indirect immunoperoxidase method with 3-amino-9-ethylcarbazole as a chromogen. Primary antibodies were Mol (CD1 lb), mAb 44 (CD1 lb), mAb 17 (CD1 lb), B-Ly6 (CD1 lc), and 5E5, a control antibody of the same isotype but irrelevant specificity. All antibodies were applied in a dilution of 1:100. The secondary antibody was a peroxidase-conjugated goat anti-mouse IgG $\mathrm{F}\left(\mathrm{ab}^{\prime}\right)_{2}$ (Dianova, Hamburg, Germany).

Detection of immune complexes. Circulating immune complexes (IC) were determined in a commercially available radial immunodiffusion assay (Freka ${ }^{\circledR}$-CIC-test; Fresenius, Bad Homburg, Germany). Briefly, IC were precipitated from serum in $2.0 \%$ polyethylene glycol, resuspended, and washed in an $\mathrm{NaCl}$-barbiturate buffer with $2 \%$ polyethylene glycol and finally transferred on plates coated with antibodies against $\mathrm{Clq}, \mathrm{C} 3 \mathrm{c}, \mathrm{IgG}, \mathrm{IgM}$, and IgA. Staining of the precipitates was performed with Coomassie blue after $48 \mathrm{~h}$ of incubation.

Immunoprecipitation. $2 \times 10^{7} \mathrm{PMN}$ were surface labeled with 1 $\mathrm{mCi}$ of ${ }^{125} \mathrm{~J}$ in $480 \mu \mathrm{l}$ PBS and $20 \mu \mathrm{l}$ lactoperoxidase $(2 \mathrm{mg} / \mathrm{ml})$. Cells were lysed in $500 \mu \mathrm{l} 0.5 \% \mathrm{NP}-40$ plus $150 \mathrm{mM} \mathrm{NaCl}, 1 \mathrm{mM}$ EDTA, 1 mM EGTA, $1 \mathrm{mM} \mathrm{NaF}$, and protease inhibitors. Lysates were precleared using $\mathrm{CNBr}$-activated Sepharose beads (Pharmacia Fine Chemicals, Uppsala, Sweden) coupled with an irrelevant (rabbit antimouse) antibody and incubated overnight at $4^{\circ} \mathrm{C}$ with Sepharose beads coupled with $\mathrm{CD} 1 \mathrm{lb}$ antibodies 44 and $\mathrm{mAb} 17$. Immunoprecipitates were washed four times and resolved by SDS-polyacrylamide gel electrophoresis analysis using a $10 \%$ polyacrylamide gel under reducing conditions (22).

Northern blot analysis. Total cellular RNA was prepared from PBL or PMN of the patient and a healthy control. $20 \mu \mathrm{g}$ of denatured RNA

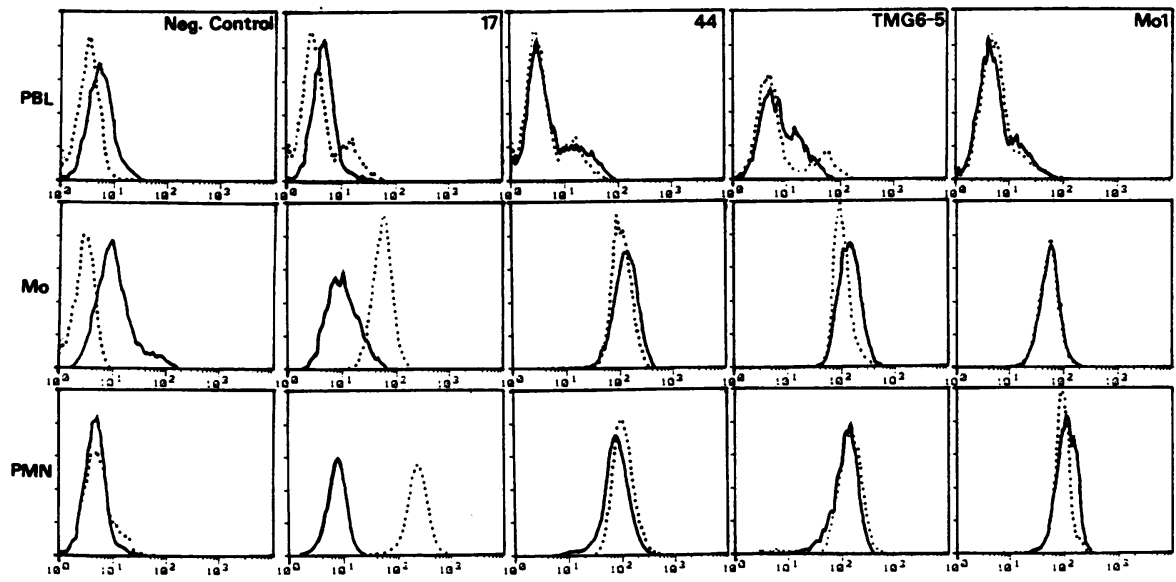

Figure 1. Expression of CD1 1b antigens 17, 44, TMG6-5, and Mol on cells of the patient $(\longrightarrow)$ and a healthy control $(\cdots)$. The phenotype of PBL, monocytes, and PMN is demonstrated. The patient's cells were negative using $\mathrm{mAb} 17$, whereas seven other antibodies revealed normal expression of their respective $\mathrm{CD} 1 \mathrm{lb}$ epitopes. mAb 44, Mol, and TMG 6-5 are shown here as representative examples for a large panel of CD1 $1 \mathrm{~b}$ antibodies tested. FACS histograms of SLE control patients were identical to the healthy control. Histograms are shown after FACScan ${ }^{\oplus}$ analysis of 10,000 cells. Fluorescence intensity is shown in a logarithmic scale on the $x$ axis, cell number in a linear scale on the $y$ axis. 

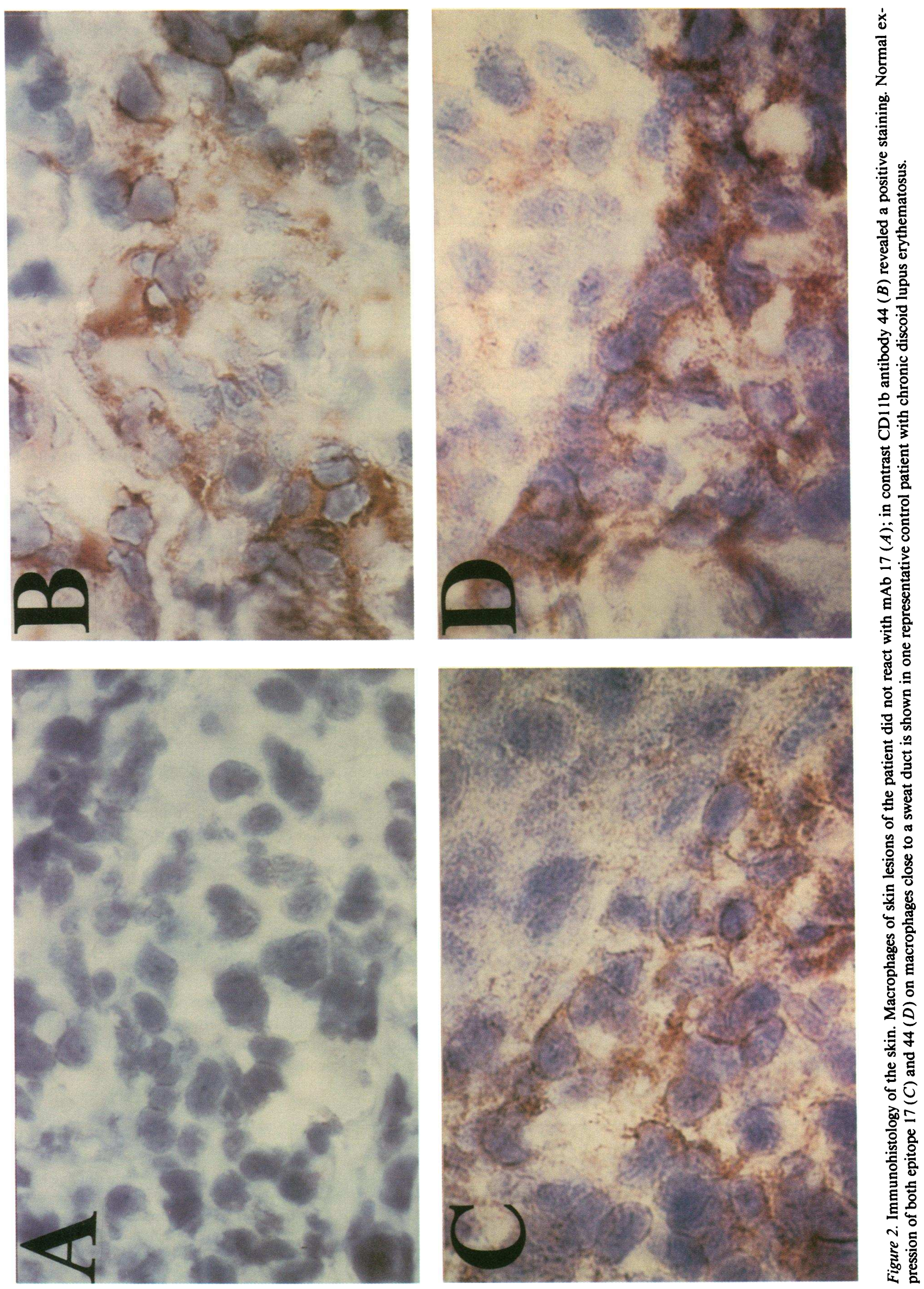


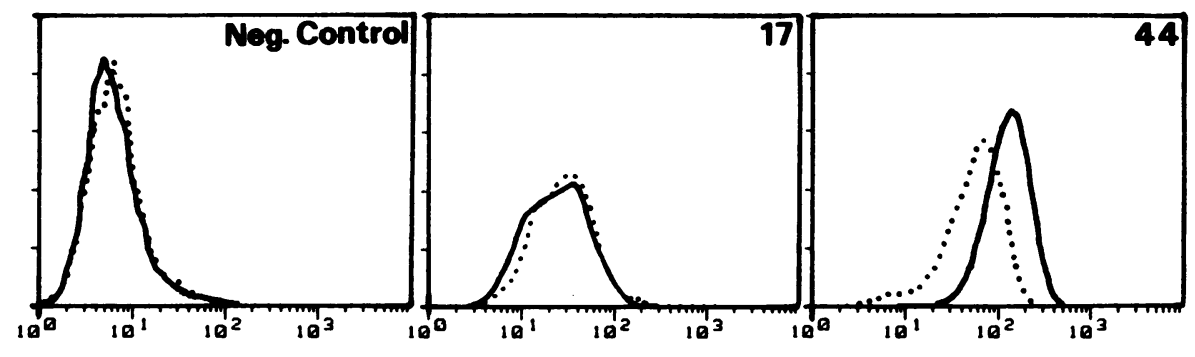

Figure 3. Activation of monocytes of the patient with PMA. Increased expression of the CD1 lb epitope 44 after incubation in PBS + PMA $0.1 \mu \mathrm{g} / \mathrm{ml}(\longrightarrow)$ compared with incubation in PBS alone $(\cdots)$ revealed mobilization of intracellular CR3 stores that were expressed on the cell surface after activation. In contrast, epitope 17 was still not expressed. from each sample was separated using a $1 \%$ agarose gel electrophoresis and subsequently bound onto a nylon membrane. Hybridization of filters was performed using cDNA probes for CD11b and CD11a (Mac-1 and pLar, kind gift of Dr. Timothy Springer, Harvard Medical School [24]) labeled with ${ }^{32} \mathrm{P}$ to a sp act of $10^{9} \mathrm{cpm} / \mu \mathrm{g}$. After extensive washing the filters were autoradiographed.

Sequencing of the L-domain of CD11b. Total cytoplasmic RNA was extracted from PBL or PMN of the patient and a healthy control by the guanidium/cesium chloride method (23). Oligo dT primed reverse transcription was performed with $1 \mu \mathrm{g}$ of total cytoplasmic RNA in a $20-\mu \mathrm{l}$ vol using $200 \mathrm{U}$ reverse transcriptase (Moloney murine leukemia virus reverse transcriptase; BRL, Eggenstein, FRG) in a standard procedure (23).

A $0.7-\mathrm{kb}$ fragment corresponding to bases $474-1,200$ of published CD11b cDNA (24) which spans the "L-domain" was amplified by PCR. PCR conditions were as follows: 20 pmol of each primer (upstream: 5'-ccagaagttcccagaggccc-3', downstream: 5'-ccaccgcccagtcatagctc-3'), $200 \mu \mathrm{M}$ dNTP, $2 \mathrm{U}$ Vent polymerase, and $1 \mu \mathrm{l}$ of the reverse transcriptase reaction in $100 \mu \mathrm{l} 1 \times$ Vent buffer (New England Biolabs, Schwalbach, FRG) were denatured $\left(300 \mathrm{~s} / 95^{\circ} \mathrm{C}\right)$ followed by 40 cycles $60 \mathrm{~s} / 95^{\circ} \mathrm{C}, 80 \mathrm{~s} / 54^{\circ} \mathrm{C}, 90 \mathrm{~s} / 75^{\circ} \mathrm{C}$, and a final extension of 120 $\mathrm{s} / 75^{\circ} \mathrm{C}$. PCR fragments were then gel purified on a $1.5 \%$ agarose gel, phosphorylated using $8 \mathrm{U}$ polynucleotide kinase (Boehringer, Mannheim, FRG) under standard conditions (23) and cloned in both orientations into the EcoRV site of the pBluescript $\mathrm{KS}(+)$ vector (Stratagene, Heidelberg, FRG). Six clones derived from two different PCRs were sequenced in both strands using a sequencing kit (Amersham, Braunschweig, FRG).

\section{Results}

A CR3 defect is present on all CD11b+cells. Granulocytes (PMN), Mo, and PBL of the patient and 20 controls with systemic lupus erythematosus were tested for the expression of the $\mathrm{C} 3 \mathrm{bi}$ receptor using various $\mathrm{CD} 1 \mathrm{lb}$ antibodies. The $\mathrm{C} 3 \mathrm{bi}$ binding site of CR3, defined by monoclonal antibody 17, was not expressed on PBL, Mo, and PMN of the patient (Fig. 1). In contrast, seven other CD11b epitopes tested were present in normal density (Fig. 1). Control cells exhibited normal expression of all CR3 antigens including epitope 17 (Fig. 1). This suggested a defect of the $\mathrm{C} 3 \mathrm{bi}$ receptor on cells of this patient involving the C3bi binding site. CD1 1a and CD11c, sharing a common $\beta$-chain (CD18) with CD11b, and CD18 itself were normally expressed (data not shown). The increased intensity of autofluorescence of the patient's PBL and monocytes shown by the negative control antibody may reflect an activated state of these cells in comparison to the normal control.

The same receptor defect could also be demonstrated on tissue sections of a skin biopsy. CD1 $1 \mathrm{~b}+$ cells in a skin lesion of the patient did not bind mAb 17 (Fig. $2 A$ ). In contrast, the CD1 lb antibody 44 showed a normal staining pattern (Fig. 2 $B)$. CD1 lb+ cells in skin lesions of three control patients with chronic discoid lupus erythematosus (Fig. 2, $C$ and $D$ ) and four control patients with systemic lupus erythematosus (not shown) expressed both the epitope 17 and 44.

The defect is apparently not due to autoantibodies. Since in SLE and in autoimmune mice various autoantibodies against cell surface antigens have been described, the presence of autoantibodies blocking epitope 17 had to be ruled out (25-27). In the presence of an autoantibody in the serum, decreased expression of the epitope 17 should have been observed. Therefore normal granulocytes were incubated with both serum and purified immunoglobulin $(5 \mu \mathrm{g} / \mathrm{ml})$ of the SLE patient and four healthy controls for $30 \mathrm{~min}$. Expression of epitope 17, however, was not altered after either incubation (data not shown). The patient's serum was also tested for its effect on binding of fluoresceinated EC3bi to recombinant CR3 expressed in COS cells, but again no difference was observed between the patient's serum and a heat-inactivated control serum (data not shown). Furthermore, PMN of the patient were washed three times in acidic buffer ( $\mathrm{pH} \mathrm{4.0)}$ to elute a putative autoantibody from the cell surface. However, flow cytometry revealed still no expression of the epitope 17 even after this procedure (data not shown).

In addition, monocytes of the SLE patient were activated using PMA. Expression of the CR3 epitope 44 was enhanced after activation by mobilization of intracellular CR3 stores ( 10 , $28,29)$. In contrast, monocytes of the patient did still not express epitope 17 (Fig. 3). Therefore, the patient did not appear to have intracellular CR3 stores expressing epitope 17.

As a final control, lines obtained from peripheral blood of the patient and a healthy control person were cultured for four months. Here again epitope 17 was not expressed on the pa-
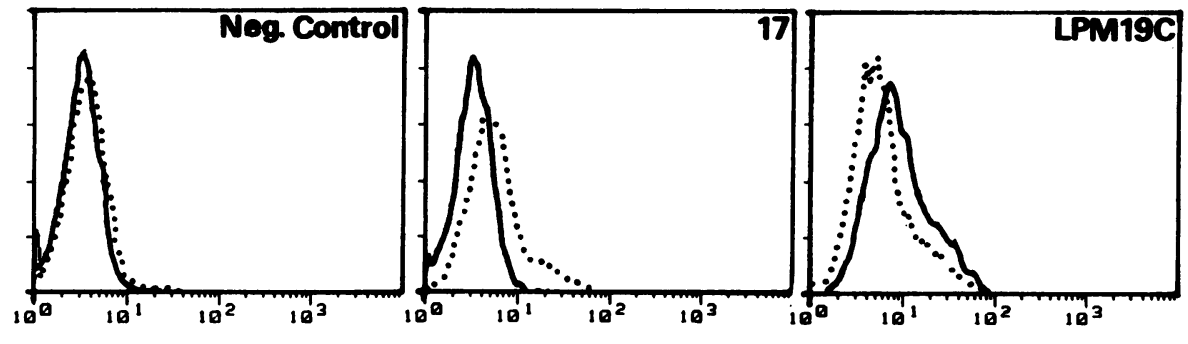

Figure 4. Phenotype of a cell line of the CR3-deficient patient after culture of 4 mo. There was no expression of epitope 17 in the patient (-); in contrast the CD11b control antibody LPM 19C detected 30\% CR3+ cells. A control line ( $\cdots$..) expressed both epitope 17 and LPM19C. 


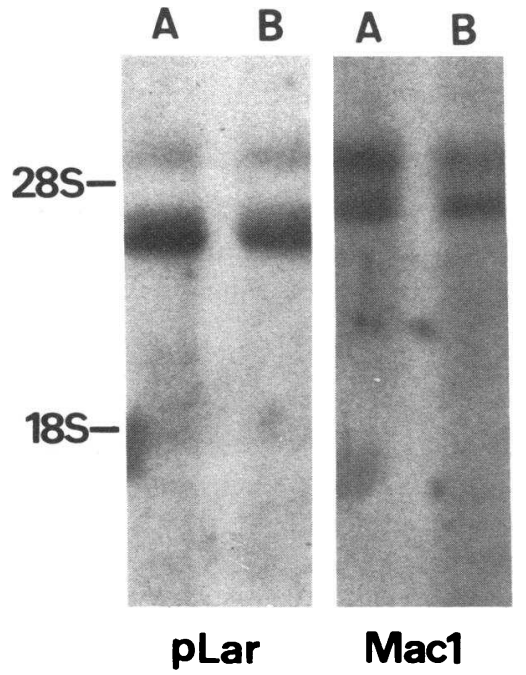

Figure 5. Northern blot analysis of PMN of the patient $(A)$ and a healthy control $(B)$ using a CD1 $1 \mathrm{~b}(\mathrm{Mac1})$ and CD11a (pLar) cDNA (24). No gross alteration of the patient's CD1 lb message was observed.

tient's PBL although $30 \%$ of the cells were CD11b+ (Fig. 4). Thus, the presence of autoantibodies was considered unlikely.

Northern blot analysis and immunoprecipitation with $\mathrm{mAb} 44$ as primary antibody revealed no gross alteration of the patient's CR3 and the encoding RNA in comparison to normal controls (Figs. 5 and 6). In the immunoprecipitation with mAb 17 no signal was obtained (Fig. 6).

Sequencing of cDNAs spanning the putative $\mathrm{C} 3 \mathrm{bi}$ binding region showed no mutation in the patient in comparison to a healthy control and published data (data not shown) (24).

Family studies. To obtain a family study, expression of epitope 17 and CD1 lb control epitopes was examined in the patient's brother and daughter. Expression of epitope 17 was normal on PMN of the brother but reduced to $\sim 50 \%$ per cell on PMN of the daughter in comparison to 30 normal controls as determined by flow cytometry (data not shown). The parents could not be examined.

Functional consequences of the $C R 3$ defect. To test whether the defect in the C3bi binding site leads to functional consequences binding of the ligand $\mathrm{C} 3 \mathrm{bi}$ to its receptor was examined in a rosetting assay. PMN of the patient and controls were incubated with erythrocytes loaded with $\mathrm{C} 3 \mathrm{bi}$ as described above. Only $2 \%$ of the patient's PMN formed rosettes compared with $45 \%$ of a control (Fig. 7). C3bi rosetting could be decreased to $2 \%$ in controls by preincubation of the cells with mAb 17, demonstrating that mAb 17 interferes with the C3bi binding site. In contrast, rosette formation of the patient's PMN was not altered by addition of mAb 17 (Fig. 7).

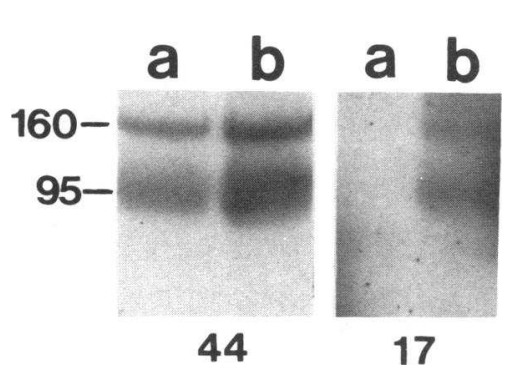

Figure 6. Immunoprecipitation from PMN of the patient $(a)$ and a normal control $(b)$ using $\mathrm{mAb} 44$ and $\mathrm{mAbl} 7$ as precipitating antibodies. Precipitation with $\mathrm{mAb} 44$ revealed a normal size of the patient's CD11b ( 160 $\mathrm{kD})$, whereas $\mathrm{mAb} 17$ did not precipitate the patient's CDIlb.

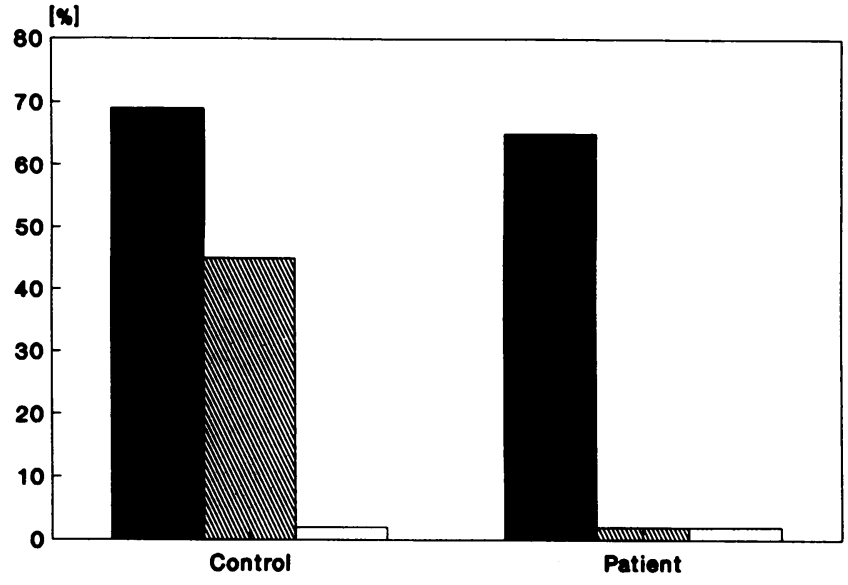

Figure 7. PMN rosetting with C3bi- and C3b-loaded erythrocytes. A representative example of three independent assays is shown. Normal control cells formed $69 \%$ rosettes with C3b ( $\square$ ) and $45 \%$ with C3bi (ه). Preincubation with mAb 17 blocked the formation of rosettes with C3bi almost completely ( $\square$ ). In contrast, the patients' PMN also formed $65 \%$ rosettes with $\mathrm{C} 3 \mathrm{~b}(\boldsymbol{\square})$, but only $2 \%$ with C3bi (ه) Preincubation with mAb 17 ( $\square$ ) did not further influence rosette formation with C3bi. Rosetting was performed as described in Methods.

Granulocyte phagocytosis of immune complex-loaded bacteria is mediated via Fc and complement receptors. To test for the functional impact of the $\mathrm{C} 3 \mathrm{bi}$ receptor defect on phagocytosis, opsonized FITC-labeled $E$. coli were incubated with PMN and phagocytosis of opsonized $E$. coli was compared to that of healthy controls (Fig. 8 ). Only $60 \%$ of patients' PMN compared to $85 \%$ of controls ingested $E$. coli. After blocking the contribution of the low affinity Fc receptors to phagocytosis by preincubation with CD16 and CDw32 antibodies the defect was even more pronounced: Only $30 \%$ of PMN compared with $60 \%$ of controls phagocytosed $E$. coli under these conditions, thus demonstrating a defect of $\mathrm{C} 3$ bi mediated phagocytosis. In contrast, adherence of PMN was not impaired in comparison to three normal controls as has been shown for patients with leukocyte adhesion deficiency (data not shown).

\section{Discussion}

While the etiology of SLE is still unclear, decreased IC clearance is considered as one major factor in the pathogenesis of this disorder $(30,31)$. However, it is not known whether such decreased clearance is one of the prerequisites or merely a secondary phenomenon following production of large amounts of IC after the onset of disease. A high percentage of patients lacking complement components $\mathrm{C} 2$ or $\mathrm{C} 4$ has been described to be associated with SLE or at least SLE-like syndromes $(4,5$, 32,33 ), showing that deficient complement dependent solubilization and clearance of IC does contribute to the emergence of disease manifestations in this disorder.

Here a patient with SLE is described exhibiting a defect of a complement receptor 3 epitope. The C3bi receptor CR 3 is considered to play the major role in phagocytosis and thereby in clearing of IC $(34,35)$. The receptor is also important in the activation of CD1 lb-positive cells, such as lymphocytes, natural killer cells, macrophages, and granulocytes (36-38). Our patient suffering from a particular form of SLE with panniculi- 


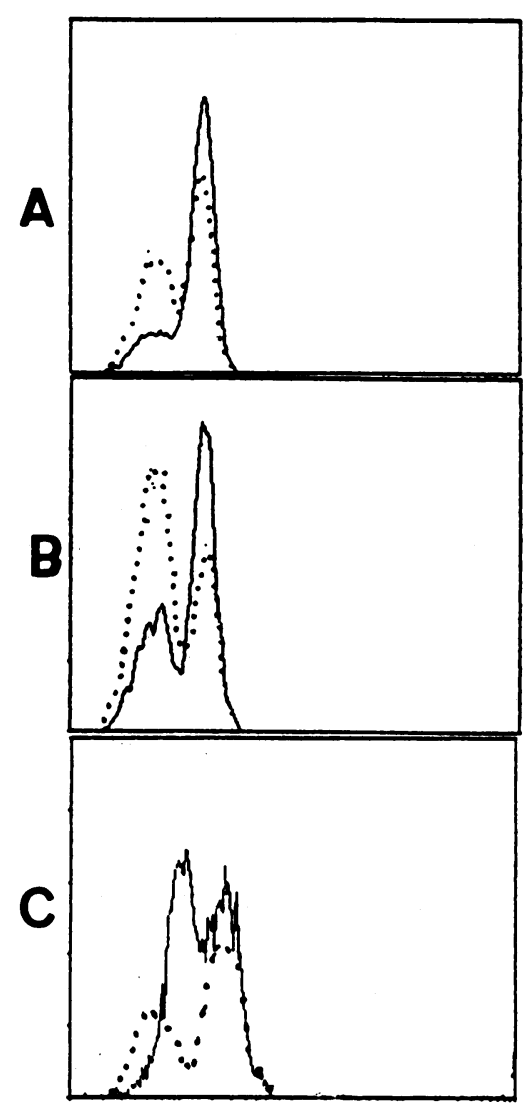

Figure 8. Phagocytosis of opsonized FITC-labeled $E$. coli. $(A)$ Phagocytosis of $E$. coli was $85 \%$ for control PMN (-) compared with only $60 \%$ for the patient ( $\cdots)$. (B) After preincubation of PMN with $\mathrm{CD} 16$ ( $\mathrm{Fc} \gamma \mathrm{RIII})$ and $\mathrm{CDw} 32$ (Fc $\gamma$ RII) antibodies $60 \%$ of control PMN compared to only $30 \%$ of the patient's cells phagocytosed E. coli. (C) After preincubation with mAb 17 phagocytosis of a healthy control is inhibited to $55 \%$. In contrast, phagocytosis of the patient was not further reduced.

tis lacks the expression of the CD1 $1 \mathrm{~b}$ epitope 17 , one important functional epitope of the $\mathrm{C} 3 \mathrm{bi}$ receptor. Two alternatives may explain this deficient expression. First, an autoantibody against the $\mathrm{C} 3 \mathrm{bi}$ receptor could be responsible for the missing expression. Careful analysis of the effect of the patient's serum on normal cells and CR3 transfectants as well as examination of long-term cultured cell lines not expressing the C3bi receptor epitope 17 has revealed no evidence for the presence of such autoantibody, rendering the possibility unlikely. Second, the lack of this epitope can be explained by a primary gene defect or an acquired gene mutation. To test this possibility the putative $\mathrm{C} 3 \mathrm{bi}$ binding region was sequenced. A mutation was not found in this region and may therefore be localized at a different site of the CR3 or be due to a posttranslational regulatory defect for this molecule. Lack of expression of epitope $17 \mathrm{might}$ also reflect a polymorphism. However, 40 control SLE patients and normal controls did not exhibit the defect, rendering a polymorphism rather unlikely.

This is the first description of a selective defect localized in the $\alpha$-chain of CR3. However, several individuals with leukocyte adhesion deficiency, a rare defect of the common $\beta$-chain of CD1 la (leukocyte function antigen-1), CD1 $1 \mathrm{~b}(\mathrm{Mol})$, and CD1 lc (CR4), have been reported $(39,40)$. These patients lack the expression of all three receptors and are clinically characterized by recurrent bacterial infections. In contrast, our patient exhibited no increased susceptibility to bacterial infections. The symptoms of leukocyte adhesion deficiency therefore appear to be primarily caused by the leukocyte function antigen-1 adhesion deficiency or by epitopes on Mol distinct from the epitope 17 (41).

The defect of epitope 17 on CR3 is also responsible for other functional disturbances. There is no rosetting of the pa- tient's PMN with C3bi-loaded sheep erythrocytes when compared with normal controls, and phagocytosis of opsonized $E$. coli appears to be significantly inhibited. The defect in complement receptor 3 function demonstrated in this patient's granulocytes thus permitted an analysis of the relative contribution of $\mathrm{Fc}$ and complement receptor activity to the process of phagocytosis. Our results confirm earlier assumptions that IgG-Fc receptors support $\sim 40 \%$ of the phagocytic function of neutrophils and monocytes (42).

In summary, this patient with a defect in the expression of the functional epitope 17 of the $\mathrm{C} 3 \mathrm{bi}$ receptor provides further evidence that $\mathrm{CR}$ defects may contribute substantially to the pathogenesis of SLE once they are present. Moreover, the analysis of the patient's gene for the $\alpha$-chain of CR3 may provide a tool to determine definitely the binding site of $\mathrm{C} 3 \mathrm{bi}$ and respective monoclonal antibodies for the complement receptor 3 .

\section{Acknowledgments}

This work was supported by Sonderforschungsbereich 244 and 236 .

\section{References}

1. Schifferli, J. A., Y. C. Ng, J. Estreicher, and M. J. Walport. 1988. The clearance of tetanus/anti-tetanus toxoid immune complexes from the circulation of humans. Complement- and erythrocyte complement receptor 1-dependent mechanisms. J. Immunol. 140:899-904.

2. Hundt, M., and R. E. Schmidt. 1992. The glycosylphosphatidyl-inositollinked $\mathrm{Fc}$ receptor III represents the dominant receptor structure for immune complex activation of neutrophils. Eur. J. Immunol. 22:811-817.

3. Hendrich, C., J. C. Kuipers, W. Kolanus, M. Hammer, and R. E. Schmidt. 1991. Activation of CD16+ effector cells by rheumatoid factor complex. Role of natural killer cells in rheumatoid arthritis. Arthritis Rheum. 34:423-431.

4. Atkinson, J. P. 1988. Complement deficiency. Predisposing factor to autoimmune syndromes. Am. J. Med. 85:45-47.

5. Rynes, R. I. 1982. Inherited complement deficiency states in SLE. Clin. Rheum. Dis. 8:29-47.

6. Cole, F. S., A. S. Whitehead, H. S. Auerbach, T. Lint, H. J. Zeitz, P. Kilbridge, and H. R. Colten. 1985. The molecular basis for genetic deficiency of the second component of human complement. N. Engl. J. Med. 313:11-16.

7. Clark, M. R., L. Liu, S. B. Clarkson, P. A. Ory, and I. M. Goldstein. 1990. An abnormality of the gene that encodes neutrophil Fc receptor III in a patient with systemic Lupus erythematosus. J. Clin. Invest. 86:341-346.

8. Tan, E. M., A. S. Cohen, J. F. Fries, A. T. Masi, D. J. McShane, N. F. Rothfield, J. G. Schaller, N. Talal, and R. J. Winchester. 1982. The 1982 revised criteria for the classification of systemic lupus erythematosus. Arthritis Rheum. 25:1271-1277.

9. Knapp, W., B. Dörken, W. R. Gilks, E. P. Rieber, R. E. Schmidt, H. Stein and A. E. G. Kr. van dem Borne. 1989. Leucocyte Differentiation Antigens IV. Oxford University Press, Oxford.

10. Freyer, D. R., M. L. Morganroth, C. E. Rogers, M. A. Arnaout, and R. F. Todd. 1988. Modulation of surface CD11/CD18 glycoproteins (Mo1, LFA-1, p150,95) by human mononuclear phagocytes. Clin. Immunol. Immunopathol. 46:272-283.

11. McMichael, A. J., P. C. L. Beverley, S. Cobbold, M. J. Crumpton, W. Gilks, F. M. Gotch, N. Hogg, M. Horton, N. Ling, I. C. M. MacLennan, et al 1987. Leucocyte Typing III. Oxford University Press, Oxford. 590-591.

12. Nadler, L. M., P. Stashenko, R. Hardy, A. van Agthoven, C. Terhorst, and S. F. Schlossman. 1981. Characterization of a human B cell specific antigen (B2) distinct from B1. J. Immunol. 126:1941-1947.

13. Schmidt, R. E., R. P. MacDermott, G. T. Bartley, M. Bertovich, D. A. Amato, K. F. Austen, S. F. Schlossman, R. L. Stevens, and J. Ritz. 1985. Specific release of proteoglycans from human natural killer cells during target cell lysis. Nature (Lond.). 318:289-291.

14. Boyum, A. 1968. Isolation of mononuclear cells and granulocytes from human blood. Scand. J. Clin. Lab. Invest. 21 (Suppl. 97):77-89.

15. Witte, T., K. Wordelmann, and R. E. Schmidt. 1990. Heterogeneity of human natural killer cells in the spleen. Immunology. 69:166-70.

16. Dana, D., D. M. Fathallah, and M. A. Arnaout. 1991. Expression of a soluble and functional form of the human $\beta 2$ integrin $C D 11 \mathrm{~b} / \mathrm{CD} 18$. Proc. Natl. Acad. Sci. USA. 88:3106-3110. 
17. Schmidt, R. E., J. M. Michon, M. Woronicz, S. F. Schlossman, E. L. Reinherz, and J. Ritz. 1987. Enhancement of natural killer function through activation of the T11 E rosette receptor. J. Clin. Invest. 79:305-308.

18. Werfel, T., P. Uciechowski, C. Schreiber, P. A. T. Tetteroo, A. P. Neeleman, R. Kurrle, H. Deicher, and R. E. Schmidt. 1989. Activation of cloned natural killer cells via FcRIII. J. Immunol. 142:1102-1106.

19. Kazatchkine, M., D. T. Fearon, and K. F. Austen. 1979. Human alternative complement pathway: membrane-associated sialic acid regulates the competition between B and beta-1-H for cell bound C3b. J. Immunol. 122:75-81.

20. Myones, B. L., J. G. Dalzell, N. Hogg, and G. D. Ross. 1988. Neutrophil and monocyte cell surface p150,95 has iC3b-receptor (CR4) activity resembling CR3. J. Clin. Invest. 82:640-651.

21. MacGregor, R. R., P. J. Spagnulo, and A. C. Lentnek. 1974. Inhibition of granulocyte adherence by ethanol, prednisone and aspirin measured with an assay system. N. Engl. J. Med. 291:642-646.

22. Bonner, W. M., and R. A. Laskey. 1974. A film detection method for tritium-labelled proteins and nucleic acids in polyacrylamide gels. Eur. J. Biochem. 46:83-88.

23. Sambrook, J., E. F. Fritsch, and T. Maniatis. 1989. Molecular Cloning: A Laboratory Manual. 2nd ed. Vol. 2. Cold Spring Harbor Laboratory Press, Cold Spring Harbor, NY. 545 pp.

24. Corbi, A. L., T. K. Kishimoto, L. J. Miller, and T. A. Springer. 1988. The human leukocyte adhesion glycoprotein Mac-1 (complement receptor 3 , CD1 lb) alpha subunit. Cloning, primary structure, and relation to the integrins, von Willebrand factor and factor B. J. Biol. Chem. 263:12 403-12 411.

25. Boros, P., J. Chen, C. Bona, and J. C. Unkeless. 1990. Autoimmune mice make anti-Fc receptor antibodies. J. Exp. Med. 1581-95.

26. Alsenz, J., K. Bork, and M. Loos. 1987. Autoantibody-mediated acquired deficiency of $\mathrm{Cl}$ inhibitor. N. Engl. J. Med. 316:1360-1366.

27. Hartman, K. R., and D. G. Wright. 1991. Identification of autoantibodies specific for the neutrophil adhesion glycoproteins $\mathrm{CD} 1 \mathrm{lb} / \mathrm{CD} 18$ in patients with autoimmune neutropenia. Blood. 78:1096-1104.

28. Vedder, N. B., and J. M. Harlan. 1988. Increased surface expression of $\mathrm{CD} 1 \mathrm{lb} / \mathrm{CD} 18$ (Mac-1) is not required for stimulated neutrophil adherence to cultured endothelium. J. Clin. Invest. 81:676-682.

29. Pryzwanski, K. B., T. Wyatt, W. Reed, and G. D. Ross. 1991. Phorbol ester induces transient focal concentrations of functional, newly expressed CR3 in neutrophils at sites of specific granule exocytosis. Eur. J. Cell. Biol. 54:61-75.
30. Schifferli, J. A., Y. C. Ng, J. P. Paccaud, and M. J. Walport. 1989. The role of hypocomplementaemia and low erythrocyte complement receptor type 1 numbers in determining abnormal immune complex clearance in humans. Clin. Exp. Immunol. 75:329-335.

31. Schifferli, J. A., Y. C. Ng, and D. K. Peters. 1986. The role of complement and its receptor in the elimination of immune complexes. N. Engl. J. Med. 315:488-495.

32. Goldstein, R., F. C. Arnett, R. H. McLean, W. B. Bias, and M. Duvic. 1988. Molecular heterogeneity of complement component C4-null and 21-hydroxylase genes in systemic lupus erythematosus. Arthritis Rheum. 31:736-744.

33. Müller-Eberhard, H. J. 1988. Molecular organization and function of the complement system. Annu. Rev. Biochem. 57:321-347.

34. Smiley, J. D., and S. E. Moore. 1989. Immune-complex vasculitis: role of complement and IgG-Fc receptor functions. Am. J. Med. Sci. 298:267-277.

35. Fearon, D. T. 1988. Complement, C. receptors, and immune complex disease. Hosp. Pract. Off. 23:63-72.

36. Dana, N., B. Styrt, J. D. Griffin, R. F. Todd, M. S. Klempner, and M. A Arnaout. 1986. Two functional domains in the phagocyte membrane glycoprotein Mol identified with monoclonal antibodies. J. Immunol. 137:3259-3263.

37. Ross, G. D., J. A. Cain, and P. J. Lachmann. 1985. Membrane complement receptor type three (CR3) has lectin-like properties analogous to bovine conglutinin and functions as a receptor for zymosan and rabbit erythrocytes as well as a receptor for iC3b. J. Immunol. 134:3307-3315.

38. Werfel, T., W. Witter, and O. Götze. 1991. CDI lb and CD1 lc antigens are rapidly increased on human natural killer cells upon activation. J. Immunol. 147:2423-2427.

39. Arnaout, M. A., J. Pitt, H. J. Cohen, J. Melamed, F. S. Rosen, and H. R. Colten. 1982. Deficiency of a granulocyte glycoprotein (gp 150) in a boy with recurrent bacterial infections. N. Engl. J. Med. 306:693-699.

40. Dana, N., R. F. Todd, J. Pitt, T. A. Springer, and M. A. Arnaout. 1984. Deficiency of a surface membrane glycoprotein (Mol) in man. J. Clin. Invest. 73:153-159.

41. Springer, T. A. 1990. Adhesion receptors of the immune system. Nature (Lond.). 346:425-434.

42. Brown, E. J., J. F. Bohnsack, and H. D. Gresham. 1988. Mechanism of inhibition of immunoglobulin G-mediated phagocytosis by monoclonal antibodies that recognize the Mac-1 antigen. J. Clin. Invest. 81:365-375. 